\title{
The Challenges Facing the Law Commission in the 1990s
}

\author{
The Right Hon. Lord fustice Beldam*
}

An early task assigned to me as newly arrived Chairman of the Law Commission was to write the Introduction for the forthcoming Annual Report for 1984/85.' That year had included the 20th anniversary of the Law Commission and provided the opportunity to reflect how far the Commission had kept faith with the aims of its founders. It could not be denied that during the 20 years there had been many changes in the aspirations and in the staffing and methods of work of the Commission. Nevertheless it seemed to me, as I looked back over the achievements of past Commissioners, that the Commission had indeed kept faith by establishing and maintaining among informed opinion the reputation and status of an independent constitutional law reform body. It had done this through research, extensive consultation, the ability to harness specialised academic and professional opinion and, notwithstanding the occasional dissent, a capacity to agree on solutions which commanded the widest support.

In this achievement members of the Society of Public Teachers of Law have played - and are continuing to play - an outstanding part. As Commissioners, as independent consultants, as members of committees to which projects have been referred, as well as privately responding to the Commission's Working Papers, members have made invaluable contributions to the cause of law reform and to the esteem in which the Commission's work continues to be held.

My recent arrival relieved me of any inhibitions which modesty might otherwise have imposed, but not unnaturally I felt pride and satisfaction when this appraisal appeared to command extensive if not universal support. It is entirely in the tradition of the Commission that contrary views questioning this assessment of the Commission and its achievements received equal if not more attention at the Commission. In the following year, writing in the New Law fournal, ${ }^{2} \mathrm{Mr}$ Alec Samuels suggested that the Law Commission should be abolished and replaced by a department in the charge of a junior Minister and a senior official under the Lord

* Chairman, The Law Commission. This address was given at the Annual Conference of the Society of Public Teachers of Law, 1989.

1. Law Com. No. 155.

2. "The Law Commission. Do we really need it?", (1986) 136 N.L.f. 747. 
Chancellor with responsibility for law reform. Whilst not denying the Commission's considerable achievements, it had really done only the "easy things" he believed. Mr Samuels has often been a proponent of the view that the Law Commission should have a higher profile and more "political clout" to enable it to overcome the inertia of government departments towards reforms generally and to the Law Commission's recommendations in particular. ${ }^{3}$ The Commission, he believed, needed as a Chairman a forceful personality, a public presence, likely to make an impact in the corridors of power and fight the battles of the Commission to secure implementation of its recommendations.

Early in the following year Mr Richard Oerton, who was for many years an Assistant Solicitor with the Commission and a most popular and respected member of its staff, published his book $A$ Lament for the Law Commission. ${ }^{4} \mathrm{He}$ had seen the working of the Commission from the inside and he cast his critical eye over the performance of successive Chairmen, Commissioners and Parliamentary Draughtsmen. It is quite understandable that someone who has devoted a substantial period of his life working with passionate intensity to achieve the goal of codification of the law of landlord and tenant should feel a sense of disillusion that the Commission had failed to meet the challenges for which its founders created it. Whether $\mathrm{Mr}$ Oerton would have felt the disillusion, and indeed pessimism, he expresses had Parliament implementated the Commission's reports on the obligations of landlords and tenants ${ }^{5}$ on covenants restricting dispositions, alterations and change of user $^{6}$ and on forfeiture, ${ }^{7}$ is at least doubtful; there can, however, be no doubt that any consideration of the challenges which face the Law Commission into the 1990s should take full account of the serious points which $\mathrm{Mr}$ Samuels and $\mathrm{Mr}$ Oerton have made. Mr Oerton because he laments the passing of the Law Commission as, in his view, it was intended to be and Mr Samuels because he fears the ineffectual body which he believes it may become.

In fact each of them has focused on contradictions in the position of the Law Commission which were clearly perceived at the time of its creation. Astute civil servants in those departments most likely to be affected by the creation of an independent law reform agency ${ }^{8}$ raised questions about the extent of the Commission's role and about its responsibilities. In the result, they were left unresolved so that they could be worked out pragmatically as time went on. Much has already been written about these difficulties. At the Colloquium which was held in 1986 to mark the 20th anniversary of the founding of the Law Commission and of the Faculty of Laws at Queen Mary College many suggestions were put

3. "Personal View: 20 years of Law Reform", (1985) 135 N.L.f. 808.

4. Richard Oerton joined the Law Commission in 1972 and became an Assistant Solicitor in 1978.

5. Law Com. No. 67.

6. Law Com. No. 141.

7. Law Com. No. 142.

8. E.g., the Home Office. 
forward to overcome some of those which remain. ${ }^{9}$ To continue to develop the role of an independent constitutional law reform body, while maintaining the quality and standard of its work, will I think present the Commission with a continuing challenge into the 1990s.

In some respects the altered aspirations of the Commission and the changes in its methods of work have eased the difficulties perceived at the time of its creation. First and foremost of the difficulties over which argument took place was the question of the Commission's independence. ${ }^{10}$ Was the Commission to possess a power of initiative so that it could undertake of its own accord studies in branches of the law with which government departments might be intimately concerned? If so, a report recommending legislation which the department was unwilling to introduce could represent an embarrassing challenge to the Minister concerned. There could be no question of a body such as the Commission failing to publish its report. If, therefore, the Commission was to be an independent body in the true sense of the term its activities should be confined to areas of the law which were not the responsibility of specific departments. Such a view, however, conflicted with the aspiration that the Law Commission should have responsibility for all the law. The advocates of the idea of a Law Commission ${ }^{11}$ saw it as one of its prime functions to ensure that legislation introduced by government departments did not conflict with an overall plan for comprehensive law reform. The second objection raised to the creation of a Law Commission was of particular concern to the Home Office who were responsible for providing the staff and facilities for the Criminal Law Revision Committee. The Home Office was not only responsible for the criminal law and its administration but it was in a position to influence the subjects on which the Committee worked and the terms in which they were referred to the Committee. If the Commission were to have responsibility for all the law, then the Home Office argued it could have an adverse affect on the responsibility of its Ministers for the state of the law in the criminal courts. Similarly, they argued, Ministers responsible for the state of the law in their respective fields could also find that the Commission was straying into their preserve. Ironically such a view seems to have supposed that the recommendations of the Law Commission would in fact be enacted with little chance of debate or change being made during the process of legislation. Ministers would in effect be bound to implement the recommendations of the Commission even though they might not support the particular reforms.

Also discussed were the further difficulties posed by the legislative procedures of the House of Commons. It was realised at once that comprehensive law reform might well produce a substantial demand on legislative time. Consequently a need

9. For the papers presented see Graham Zellick (ed.), The Law Commission and Law Reform. London: Sweet \& Maxwell (1988).

10. Described by Lord Scarman as "considerable, but not total", Jarreharel Nehru Memorial Lecture 1979 but by Mr Samuels as "spurious", (1986) 136 N.L.7. 808.

11. Lord Gardiner and Professor Andrew Martin Q.C. 
was perceived to change the procedure of the House of Commons to make the passage of law reform Bills easier. At about this time the Select Committee on Procedure of the House to consider the expediency of appointing a Committee for the Second Reading of Bills, so reducing the time required for proceedings of such Bills in the House, was set up. In its Report ${ }^{12}$ the Committee considered ways in which the passage of law reform Bills might be facilitated, and pointed out that the mere description of them as law reform Bills did not necessarily mean that large questions of policy or questions likely to give rise to differences on party lines might not arise. Thus the Committee, contrary to some distinguished lawyers, appreciated that even law reform proposals which on the face of it appeared uncontroversial might give rise to political differences. The value of the special Standing Committee Procedure of the House of Commons, in considering law reform proposals, was emphasised by the Attorney-General, Sir Patrick Mayhew, when he spoke at the Colloquium in 1986 . He instanced the hearing of evidence by such a Committee during the passage of the Criminal Attempts Bill in 1981 and of the Matrimonial and Family Provision Bill, 1984, as examples of the way in which such a procedure can serve to still prejudice and alarm at Commission proposals. ${ }^{13}$

At the time of its creation it was expected that one of the principal tasks of the Law Commission would be to codify whole branches of the law. ${ }^{14}$ Obviously any Code Bill was likely to be a very substantial measure but, although concern was expressed at lack of legislative time for Law Commission Bills generally, there was no discussion in depth about the difficulty which would be presented by a Bill which codified a whole branch of the law such as criminal law or the law of landlord and tenant. Although it is already difficult to recapture the spirit of 1965 , from contemporary records and debates and the aims of the Commission's founders it is difficult to avoid the conclusion that in the mid-1960s law reform was seen as a desirable aim in itself. There was little or no discussion about the resources which would be needed for the Commission nor about its overall cost. Still less was there a discussion on whether a Commission would be "cost effective". The need for a Commission was clearly perceived and the immensity of the task which it was given to do (to take and keep all the law under review) ensured that in years to come there would be plenty of work to which it could turn its attention. Implementation would surely follow the recommendations and if legislative time was a problem it would no doubt be somehow found. It is therefore not surprising that the Commission for which $\mathrm{Mr}$ Oerton sounded his lament was a body which he perceived ought to be staffed by lawyers dedicated to reform, whose eyes were firmly on the coherence and structural elegance of the law, rather than on mere practical utility, who could make law reform their professional career rather as Parliamentary Draughtsmen might make a career of drafting Parliamentary Bills.

12. 1st Report, Feb. 1965.

13. The Law Commission and Law Reform, supra n. 9.

14. See s. 3(i) Law Commissions Act 1965. 
By the $1980 \mathrm{~s},{ }^{15}$ however, a profound change had set in. Public spending had reached an unacceptable level (it was said) and consequently economies were called for. Control of public spending required that all projects needed to be justified and priorities established. All departments, including the Lord Chancellor's Department, had to compete for a limited amount of funds. Better use needed to be made of the skilled staff available. So it was that the staff inspection review which was carried out at the Law Commission in the early 1980 s brought disillusion to $\mathrm{Mr}$ Oerton and I expect to a number of others.

In a number of its major projects the Commission had set itself challenges which it had been unable to meet. Having abandoned its codification of the law of contract and of the law of landlord and tenant, the Commission was still trying to produce a criminal code. ${ }^{16}$ At that stage the Commission appeared as far as ever from concluding it. Nevertheless the thoroughness and the quality of the Commission's work was widely recognised.

The Commission might thus have seemed a serious candidate for economies in keeping with the new zeals and new ethos for public expenditure. The fact that the Commission has survived, virtually in unaltered form, though with less ambitious aspirations and different methods of work, is in itself a tribute to the work of former members of the Commission in meeting the challenges of the past. If in deciding on its programmes of work or in producing its recommendations the Commission had been perceived as contributing little to the improvement of the law it would not have survived.

Nevertheless, as readers of our Annual Reports will know, the staff inspection report brought about a profound change in the way in which the Commission was to undertake its work. Five of the six senior solicitors in the government service were eventually withdrawn and the Commission was expected to replace their expertise as and when required by commissioning work outside and by taking on additional research assistants. At the same time the Commission, in order to make the best use of the financial resources available to it, had to cost its projects and to consider priorities. A number of projects which had been started several years earlier which were long and difficult remained to be completed. In addition the Commission began to turn its attention to less ambitious projects. Drawing on the work which it had previously done, it produced reports on particular aspects of the law of landlord and tenant and is continuing to do so. In the criminal law the Commission continued systematically but steadily to work towards a Criminal Code. With the generous and outstanding assistance of the Code Team from the Society of Public Teachers of Law of Professor Smith, Professor Griew and Professor Dennis, completion of this important project became a reality. ${ }^{17}$ I view the final implementation of the Criminal Code as one of the major challenges facing the Commission in the 1990s. No-one should underestimate the difficulties

15. Its onset was already noted in 1979 by Lord Scarman.

16. Law Com. No. 56, 8th Annual Report, paras. 3 and 4.

17. Law Com. No. 143 and No. 177. 
which will have to be faced and I shall return to them later. Nevertheless publication of the Code on April 1989 was among the greatest of the Commission's achievements and it gave a significant boost to the morale of the Commission. There are now many who believe that the enactment of the Code would make a major contribution to simplification and rationalisation of the criminal law of this country.

In the First Annual Report of the Commission, under the subject of the future of law reform, the Commission stated:

"The most important lessons for the future learnt during the first year of the Commission's existence are two: that haste is the enemy of sound law reform and that law reform must concern itself as much with the form, arrangement and procedures of the law as with its substance."

My predecessor, Lord Justice Gibson, in his lecture on the Law Commission ${ }^{18}$ expressed the view that the Commission would probably not wish for very much longer to carry out its duty of reviewing all the law by deciding what to do next within the existing programmes. It seemed to him likely that more resources would be applied to shorter projects which offered the prospect of useful reforms. Some were already planned in the law of landlord and tenant. He saw the Commission doing more of its work in response to government references, as it was then doing in contract law, and in providing assistance to departmental projects as the team led by Brenda Hoggett was then doing in preparing the review of child care law. There was no danger he felt of the Commission ceasing to be the watchdog of all the law and dwindling into something resembling a law research division of a Ministry of Justice. He saw the problem as one of the best ways of allocating resources. The Commission had, and should develop, the ability to examine, to organise and to prompt more in the way of reviewing the law and of projects of law reform than it could carry out by the use of its own permanent resources. The Commission has actively pursued these ideas. Indeed during Lord Justice Gibson's time at the Commission he, in conjunction with Professor Jolowicz, had already promoted an important Seminar on civil procedure. This Seminar, which was held in September 1985, stimulated widespread discussion which in due course led to the Civil Justice Review set up by the Lord Chancellor's Department. In its recommendations the Review suggested two topics which might be referred to the Law Commission. The first was class actions and the second the hearsay rule. I shall return to them later.

During the past three years the Commission has carried these ideas into practice. Its Criminal Law Team has prepared papers on a number of contemporary problems for presentation at Seminars organised by the Judicial Studies Board. It says a great deal for the foresight of Mr Brian Davenport QC,

18. "The Law Commission", [1986] Current Legal Problems, p.57. 
whose term as Commissioner responsible for the criminal law expired at the end of last year, that all of these studies have been of influence in their respective spheres in one way or another. The stimulation of discussion on topics of contemporary importance ${ }^{19}$ and debate and the informing of opinion by accurate, thorough and detailed research both on their history and on the way in which the law has developed in other common law countries is, I believe, an important use of the Commission's resources. Whilst work of this kind is not contained in any programme item, nor has it been referred to the Commission under Section 3(1)(e), the promotion of reform of the law appears clearly from the Law Commissions $\mathrm{Act}^{20}$ as a principal purpose for which it was set up. The Commission has from its early days perceived that the encouragement of discussion on aspects of the law which appear outdated and in need of change is an important step in sounding public opinion.

There are now 1,500 Judges, full and part-time, who attend Seminars of the Judicial Studies Board. With first-hand experience of the difficulties currently presented by the procedure and practice in the criminal courts, they are an obvious source of advice on these projects. The Commission recognised the value of this source of practical experience when it set up the Consultation Groups which considered the provisions of the draft Criminal Code. The papers presented at several recent Judicial Studies Board Seminars have been very well received and the Commission in turn has received useful comments. Quite apart from clarifying particular aspects of law and procedure, by undertaking studies and publishing papers of this kind the Commission fulfils its duty to promote law reform by keeping interest alive and by encouraging many who perhaps otherwise would not make their views known to take part in the process of change. On the Civil side of the Judicial Studies Board too, Trevor Aldridge the Commissioner responsible for Property Law has lectured on recent developments in the law of Landlord and Tenant. These initiatives not only stimulate the interest of the judiciary in changes in the law, they create awareness that the Commission is as concerned to improve form and procedure in its practical day to day aspects. The reference received by the Commission to consider the law of corroboration in criminal cases is a sign of this awareness and presents the Commission with a new and stimulating challenge in the criminal law. ${ }^{21}$

In addition to embarking on these smaller projects it seemed appropriate to review the progress which the Commission had made with its programme items which represent the major part of its work. Work which remained to be done could form the basis of a fourth programme of law reform which had been under discussion for some time. In addition the Commission wished to add new projects

19. The Team prepared papers on "Sentencer as Factfinder", "Binding Over in the Crown Court" and "Challenge for Cause".

20. Section 1(i) "For the purpose of promoting the reform of the law ..."

21. The reference was made by the Lord Chancellor under s. 3 I(e) of the Law Commissions Act 1965. 
upon which it hoped to work in the near future. The need for the Lord Chancellor to justify expenditure on the Commission's projects meant that it was obviously desirable to discuss the programme with his officials. When the Commission's first programme was being discussed Lord Gardner attended meetings with the Commission and took part in the discussions. So we discussed our plans with the Lord Chancellor's officials. In these talks the form and purpose of a Law Commission programme became a significant issue. The duty of the Commission to prepare and submit to the Lord Chancellor from time to time such programmes is a fundamental one. The Commission cannot, of course, work on programme items until they have been approved by the Lord Chancellor but, as Professor Stephen Cretney has said, ${ }^{22}$ two of the most important advantages of the programme technique are:

1. That by producing a programme the Commission not only makes public its views that the law on this subject is in need of simplification and reform, it also demonstrates a commitment that it will work on those items as and when its resources permit.

2. It confers a mandate on the Commission to be involved in the work of reform of the law on that subject.

In the course of these discussions the Commission was aware of the change of ethos from 1965 and of the need for realism. It seemed obvious that little purpose would be served by seeking approval for a fourth programme which contained many items of great scope on which the Commission could neither begin work itself nor commission independent research for several years. Lord Gardner replying to the debate in the House of Lords $^{23}$ on the Commission's first programme gave no help about the size or duration of a programme. He described the words "To prepare and submit ... from time to time programmes" as beautifully flexible and as capable of covering programmes of ten years duration or three months. It is of course always open to the Lord Chancellor or any other Minister to refer specific questions of law reform to the Commission under $\mathrm{s.3}(1)(\mathrm{e})$, and this suggests that it was intended that programmes should be submitted at regular but not necessarily equal intervals. After a space of fifteen years, I believe a further programme was overdue! As previous Chairmen have said, in the overall plan of the Commission's work there is a place for each type of project. However in addition to deciding the scope and object of a programme of law reform, a management plan of the Commission's year to year work is needed to decide what resources are necessary and to enable the Lord Chancellor's Department to convince the Treasury that they should be provided. The resources will need to cover work not only on Programme items and on references made to the Commission, but also the work undertaken by the Commission in keeping all

22. "The Programmes - Milestones or Millstones", The Law Commission and Law Reform, supra n.9. 23. H.L.Deb. 9th Dec. 1965, Vol. 467. 
the law under review. Consequently both must be realistically chosen. The need to justify the Commissioners' projects and their priority in this way poses challenges for the Commission, which was certainly not perceived at the time of its creation. Nevertheless these challenges have arisen against a background which may enable the Commission to fulfil more effectively its role as a watchdog of all the law. I mentioned the reluctance which some government departments originally expressed at the idea of accepting the Commission's proposals or of working with the Commission to achieve reform. It is no secret that recruitment of lawyers for government service has become increasingly difficult and that the shortage is now acutely felt. It is a shortage from which the Commission itself is not entirely immune. One obvious way in which government departments could try to diminish the effect of this shortage would be to seek assistance from the Commission whose duty it is to give advice and information under s.3(1)(e). Of course the department would have to feel confident that the Commission would produce advice and assistance of the calibre on which it has built its reputation and that it will do so on time. To build up this confidence the Commission must gradually increase its connections with the government departments in question. An outstanding example of just how successful such co-operation can be may be gauged from the results of the work of Professor Hoggett's Family Law Team with the Department of Health \& Social Security and with the Lord Chancellor's officials in producing the Children's Bill currently before Parliament. Equally in the criminal law the Commission has made an encouraging start in collaborating more closely with the Home Office in trying to ensure that the appropriate priority is accorded the projects undertaken. One of the fruits of this collaboration was Law Com. No. 180, "Jurisdiction over Offences of Fraud and Dishonesty with a Foreign Element", which resulted from a joint initiative between the Commission and the Home Office and which incidentally also enabled the Commission to do one of the difficult things which had been left undone in 1978 when the Commission reported on the "Territorial and Extraterritorial Extent of the Criminal Law" (Law Com. No. 91).

In outlining the background to our fourth programme of law reform, I have tried to show that maintaining and developing the Law Commission's role as an independent constitutional law reform body is, in itself, no mean challenge. I would now like to mention some of the more specific challenges contained within the fourth programme which are likely to set the agenda at least for the early years of the 1990s.

\section{The Criminal Law}

To try to promote implementation of Law Commission proposals has not generally been seen (overtly at least) as part of the Commission's function. Of course our reports are couched (confidently, I hope) in persuasive terms seeking to convince government, or indeed in the absence of government a reforming 
backbencher, of the virtues of our proposals. Yet, as I have already pointed out, in s. 1(1) of the Law Commissions Act promotion of law reform is the very rationale of the Commission's existence. Once a Report had been delivered to the Lord Chancellor, the Commission seemed powerless to prevent the contraction of what a former Commissioner so graphically called "legislative pneumoconiosis". ${ }^{24}$

In his address to the Law Reform Agencies Conference in Hobart in July 1981 the then Chairman of the Law Commission, Mr Justice Kerr, speaking on the political aspects of law reform in the United Kingdom, said:

"It is the necessary political will which we must create. But this can only be done by a long and wearisome process of persistent persuasion and pressure."

When the Commission with the Code Team had to decide on the contents of a draft Criminal Code, the Commission was in what I understand the Americans to call "a no win situation". If the Commission codified existing law with all its difficulties and inconsistencies in the face of the many reform proposals which had been produced during the last twenty years, it would have been said that there was no point in implementing a Code in that form for it would have immediately been out-of-date. On the other hand, if the reform proposals were codified, some of which were controversial, implementation of the Code would require substantial Parliamentary time, so no government would be willing to implement it. I believe the Commission was right to decide on the strategy adopted of codifying the proposals of responsible and distinguished bodies such as the Butler Committee ${ }^{25}$ and the Criminal Law Revision Committee. It seemed more likely that the difficulties raised by the second approach could be overcome than those of the first.

In the result, therefore, the Code included proposals on incapacity and mental disorder designed to give effect to the Butler Committee's proposals but modified in the light of further consultation. The provisions relating to offences against the person were based upon the recommendations of the 14th Report of the Criminal Law Revision Committee ${ }^{26}$ and had been scrutinised by a small group of practitioners presided over by Lord Justice Lawton under whose chairmanship the Criminal Law Revision Committee had produced its proposals. Although the Commission was well aware that some of the proposals of the 15th Report of the CLRC on sexual offences ${ }^{27}$ in 1974 might prove controversial, nevertheless it would have been quite inconsistent not to have included those provisions and

24. For examples of the concern of previous Commissioners, see Professor Cretney "The Politics of Law Reform - A View from the Inside" and Dr Peter North "Law Reform Processes and Problems", 101 L.Q.R. 358.

25. Report 1975, Cmnd. 6244.

26. 1980 Cmnd. 7844 .

27. 1984 Cmnd. 9213. 
those of the 16th and 17th Reports ${ }^{28}$ on the same topics.

When the Criminal Code was published on 17th April 1989 the reactions were almost universally favourable but perhaps predictably the provisions of the 15 th Report of the Criminal Law Revision Committee concerning buggery and incest did prompt criticism and eventually lead to a Home Office spokesman in answer to a Parliamentary Question confirming that the government had no intention of implementing such recommendations.

At the time of the decision to include in the Code the proposals of the CLRC's 14th Report on offences against the person, the Commission did not know that a Select Committee of the House of Lords would shortly be set up to consider the law of murder and sentences of life imprisonment. The report of the committee presided over by Lord Nathan was published on 18th September 1989.

The completion of the Criminal Code and its publication in April this year presents the Commission with an entirely new type of challenge in the years ahead. That is to consider ways in which to promote the Code and ensure that it passes onto the Statute Book. It is important that the impetus which the project has gained should not be lost. Many practitioners are convinced that it represents the way forward in the criminal law but gravely underrate the difficulties of implementation. How should we proceed? One way of reducing opposition to the Code would be to produce a supplementary report on those controversial subjects. Further consultation would be needed and proposals would be presented in Bills drafted in a style which is consistent with the scheme of the Code. If these Bills were enacted, the prospects for the Code would be enhanced for it is noticeable that where there is recent legislation based upon reports of the Commission, as for example in criminal damage ${ }^{29}$ and public order offences, ${ }^{30}$ no criticism has been directed at the Code as far as I am aware.

At the same time, I believe the Commission must lose no opportunity of stimulating discussion on the best way to secure the Code's implementation. To this end, I hope the Commission will encourage and support Seminars and discussions organised for this purpose. One such Seminar is planned for January 1990 in Cambridge and I am sure others will follow.

The promotion of the Code will in itself be a major challenge but there are other challenges facing the Commission in the criminal law which by themselves could be regarded as formidable. Two projects which have occupied the Commission for a considerable time are Conspiracy to Defraud and Binding Over to Keep the Peace. No-one who has worked on the subject of Conspiracy to Defraud would underestimate the difficulties facing the Commission. Should the principle on which the Criminal Law Act 1977 was founded, that acts lawfully done by one person should not become unlawful merely because two or more persons agree that they shall be done, prevail over the arguments of convenience for retaining an

28. 1984 Cmnd. 9329,1985 Cmnd. 9688.

29. Law Com. 29.

30. Law Com. 123. 
offence which enables prosecutors to present the real scope of a defendant's activities in more readily understandable form than an indictment con caining 61 or 62 counts; whether the retention of such an offence infringes ihe underlying principle that every accused person is entitled to know precisely the offence charged against him and if the argument of principle prevails, whether a general fraud offence can be created which is consistent with the continued existence of the present Theft Acts offences.

These challenges are not new. They have already defied previous efforts of the Commission, the CLRC and the Roskill Committee. ${ }^{31}$ An acceptable solution will, I am sure, be found.

Binding Over too, a question referred to the Commission in November 1980, presents an equally difficult challenge. Notwithstanding the praise lavished by Blackstone on preventive justice, ${ }^{32}$ very real questions are now asked about the legitimacy of the process in modern times of binding over to keep the peace and be of good behaviour. It has, however, undoubted utility in some situations. It is economical in court time and is widely supported by magistrates and judges alike.

As will be seen from item 5 of our fourth programme, the Commission expects shortly to begin work on a project on the preliminary offence of Aiding and Encouraging Crime. Work on corroboration has already begun. All these projects amount to a programme of work in the criminal law as demanding as any the Commission has ever undertaken in this field.

\section{Family Law}

There are few subjects which have presented the Commission with greater or more sustained challenge during its existence than family law. I would approach any forecast of future challenges with great diffidence in any case but do so particularly in the presence of Professor Hoggett who in addressing the Solicitors' Family Law Association Annual Conference earlier this year pointed out the courage that is needed to predict the future course of any developments in family law.

In her address, ${ }^{33}$ Professor Hoggett drew attention to the pace of social change which had made it necessary for the Commission to keep family law under continuing review. The Family Law Team at the Commission has been particularly successful in keeping pace with social change. Its projects continue to reflect the changes in social behaviour and the climate of opinion which follows. Professor Hoggett highlighted the radical changes which have been brought about in the law relating to children by the Children Bill. The success of the co-operation between the Family Law Team at the Commission and government agencies and departments is, as I have said, one of the most encouraging features of our current

31. 1986, Fraud Trials Committee Report.

32. Bk IV, Ch. XVIII, 251.

33. "Family Law into the 1990s", (1989) 19 Family Law 177. 
programme. Professor Hoggett speculated on the results which might be achieved if a similarly comprehensive review of both substantive and procedural aspects of family law, in particular in the aspects of domestic violence and of occupation of the family home as it applies to adults, could be undertaken. If the same remedies could be available in all courts together with the ability to transfer where appropriate from one court to another upon the model of the Children Bill, a great improvement would occur in this field of law. Publication by the Commission in May last year of the discussion paper on the Ground for Divorce ${ }^{34}$ was intended to confront the problem that many believed the operation of the present law of divorce falls short of the objectives of reducing the conflict and bitterness which so often is involved. As we enter the $1990 \mathrm{~s}$, the Commission will be considering whether to propose changes in the law and whether the option discussed of divorce after a process of transition can be developed into an acceptable proposal.

The subject of Item 9 of our fourth programme, the law relating to mentally incapacitated adults, is a topic of increasing significance in a "greying" population. The Commission hopes that in undertaking the project it will be assisted by representatives of relevant government departments and other agencies who have wide practical experience and insight into the difficulties which will have to be taken.

\section{The Common Law}

The Report of the Review Body of Civil Justice considered two recommendations ${ }^{35}$ that the Lord Chancellor should commission an enquiry by a law reform agency. The first suggested an enquiry into the hearsay rule and the current machinery for rendering it admissible; the second, that a study should be undertaken by a law reform agency of the case for extending the availability of representative or class actions or establishing other procedures to be available in cases in which there were large numbers of litigants whose claims or defences have a common basis. In response the Lord Chancellor has enquired whether the Law Commission would be prepared to assist in both these initiatives. The Commission has tentatively agreed to do so. A number of other organisations are interested and involved, the Supreme Court Rules Committee, the Lord Chancellor's Department, as well as outside organisations such as the Consumer Association. A report on the hearsay rule, whilst challenging, would not take the Commission into new territory. In its report on the parol evidence rule the Commission demonstrated the value of close analytical attention to evidential rules. ${ }^{36}$ The very complicated structure which the rules relating to hearsay evidence have now assumed, could well benefit from a similar analysis.

Class actions, on the other hand, would not only take the Commission into entirely new territory. Although it is not difficult to think of some fairly

34. "Facing the Future", Law Com. No. 170.

35. Nos. 26 and 27.

36. Law Com. 154. 
straightforward alternatives to the existing rules which would give the Court greater control over multiple litigation, recent cases $^{37}$ have demonstrated how easily conflicts can arise between parties appearing to have similar interests and that there are fundamental difficulties involved in taking the conduct of an action out of the control of the individual plaintiff or defendant. To secure the full benefits of a class action procedure, however, the aim must surely be to try to ensure that one action, and one action only, should be brought to decide the various issues arising from the circumstances giving rise to the common questions of law or fact between the parties.

The concept of a class action is one largely borrowed from the American courts where it has not been wholly successful. The procedures which have been developed to deal with cases in which there are many plaintiffs who have suffered as a result of a single disaster have run up against the difficulty of ensuring that on the one hand the number of separate proceedings is reduced as far as possible and on the other that individuals are not deprived of a right of action which is their own property. This has led the courts to put in place complicated certification procedures and the "opt in" or "opt out" process of trying to secure that no person potentially affected by the outcome of the action is unfairly bound by the result. How to resolve the difficult question of substituting class rights for personal rights and how to establish satisfactory rules of procedure to protect the position of individual plaintiffs is in itself likely to be a substantial challenge. If in addition the Commission had to consider the kind of consumer class action for which the Consumer Council is pressing, ${ }^{38}$ the difficulties would be even more far reaching. ${ }^{39}$

When, in the article in the Modern Law Review to which I have referred, Mr Alec Samuels stated that the Law Commission had only really done the easy things, he was doing less than justice to the past work of the Commission. If he had said that in the course of undertaking a number of difficult projects the Commission had left undone some of the difficult things which it might have done, this would, I think, have been a more accurate and acceptable statement. A number of these difficult things have been retained in the fourth programme. Item 4 of the Law Commission's first programme concerned the civil liability for dangerous things and activities. The Commission recommended that an examination of the basic principles should be undertaken with a view to their clarification, simplification and unification. However in September $1970^{40}$ the Commission confessed it was unable to complete its work on this item although it had reached the clear conclusion on the work which it had done that the law relating to strict liability, including liability for the fault of an independent contractor was complex, uncertain and inconsistent in principle. Because it had been unable to include an

37. E.g., Davies v. Eli Lilley \& Co. [1987] 1 W.L.R. 1136.

38. "Group Actions - Learning from Opren", Oct. 1988.

39. Daar v. Yellow Cabs Co. 196767 Col. 2d 695; Re Hotel Telephone Charges $500 \mathrm{~F} 2 \mathrm{~d} 86$.

40. In Law Com. 32. 
investigation into the principles of liability governing accidents involving personal injury the Commission felt it could not confine its conclusions to accidents to property and so reported without making recommendations. Nearly twenty years later the debate about the basis of liability for injury and damage continues unabated. The trend seems now more firmly set towards the view that such liability should be borne by those who are undertaking the activity concerned and not by those who are injured or suffer loss. The rationalisation of the rules relating to different activities such as the storage of gas or oil products, the conduction of electricity, the escape of fire and water, would hardly seem beyond the scope of the Commission though it would undoubtedly present it with a considerable challenge to arrive at a solution which will be acceptable to such interested parties as insurers, contractors, employers and government departments. The complexity of many modern processes and the apparent inevitability of disasters causing injury and extensive damage suggest that the Commission should consider this question as soon as its resources allow.

When the Commission reported on contribution under item 1 of its first programme, ${ }^{41}$ it made no recommendations to answer the question whether contributory negligence should be a defence in an action for damages for breach of contract because, it said, it would call for a deeper study than could conveniently be given to it in the paper on contribution. It is a question which has continued to trouble litigants and to give rise to a significant number of cases in the Law Reports, as well as conflicting decisions. ${ }^{42}$ The Commission was asked to reconsider this question in $1987 .{ }^{43} \mathrm{At}$ that time the Commission did not have the resources available to take the matter further, though a preliminary paper was prepared. The advent of a Commissioner with special responsibility for common law subjects has meant that this matter can be reconsidered and I have no doubt that recommendations will be made before the end of 1991 .

Hardly a day goes by without there being some reference to the swift approach of 1992, though it might be more appropriate to refer to 1993. Progress towards a single European market will undoubtedly give added impetus to harmonising the laws of member states. Over the past twenty-five years there have been other initiatives directed to unifying the law of international sale of goods and the formation of contracts for sale. More recently the Vienna Convention on International Sales Law was opened for signature in 1981 and became effective on lst January 1988. The government is currently considering whether to ratify the Convention and it seems most likely that it will do so. After the Law Commission had decided to suspend work on the production of a contract code, ${ }^{44}$ it decided to publish a series of Working Papers on particular aspects of the law of contract. Within a very short period the Commission had published a Working Paper on

41. Law Com. 79.

42. See Vesta v. Butcher [1988] 3 W.L.R. 565.

43. By Lesley Anderson and Andrew Bell of Manchester University.

44. The Lord Chancellor so announced in the House of Lords on 9th July 1973. 
Firm Offers. ${ }^{45}$ As long ago as 1937 the Law Revision Committee had reported that the law on this subject was unsatisfactory and often operated unfairly. Countries based on the civil law generally regarded an offer as irrevocable either for the period of time indicated for its acceptance or for a reasonable time and broadly speaking the Vienna Convention adopts this position. Increasing trade with our European partners will inevitably lead to more and more contracts for the international sale of goods being based on the Convention and it is therefore desirable that the law on this subject should be re-examined with a view to its simplification and if possible harmonisation with those other systems. It would clearly become unacceptable to have different rules for contracts for sale of goods to a buyer in the Hague and a buyer in Birmingham. Over 100 years ago, Mellish LJ asked rhetorically whether the law is right or wrong in saying that a person who has given to another a certain time within which to accept an offer is not bound by that promise to give that time. ${ }^{46}$ The time has surely come to give him an answer!

Since $1937^{47}$ reform has been proposed to the rule that a person not a party to a contract could not sue upon it even though there were express provisions contained in the contract for his benefit. This problem still awaits solution, despite calls in the Court of Appeal and in the House of Lords for legislative reform. ${ }^{48}$

When the Commission decided to suspend work on its contract code in 1973, no further work was done on the question of third party rights in contract. The time now appears to be ripe to meet the challenge posed by this difficult problem.

\section{Conclusion}

In this review of the challenges facing the Law Commission in the 1990s I began with the assertion that one of the Commission's principle achievements was the establishment of its reputation as an independent, constitutional, law reform body whose work was held in the highest esteem. Nobody would suggest that to maintain that reputation for independence, integrity of thought, scholarship and thoroughness in meeting the individual challenges of the kind I have referred to would be an easy task but I believe with the continued support and encouragement of the Society of Public Teachers of Law, inter alia, and with the talent that the Commission continues to command it will meet and conquer those challenges as it has met and overcome the equally difficult challenges of the past.

45. Law Com. 60.

46. See Dickinson v. Dodds (1876) 2 Ch. D. 463.

47. See 6th Interim Report, Law Revision Committee.

48. Dillon LJ in Forster v. Silvermere Golf $\mathcal{E}^{\prime}$ Equestrian Centre (1981) 125 S. \%. 397; Wooden Investment Development Ltd. v. Wimpey [1980] 1 All E.R. 571, Lord Salmon, Lord Keith and Lord Scarman. 